
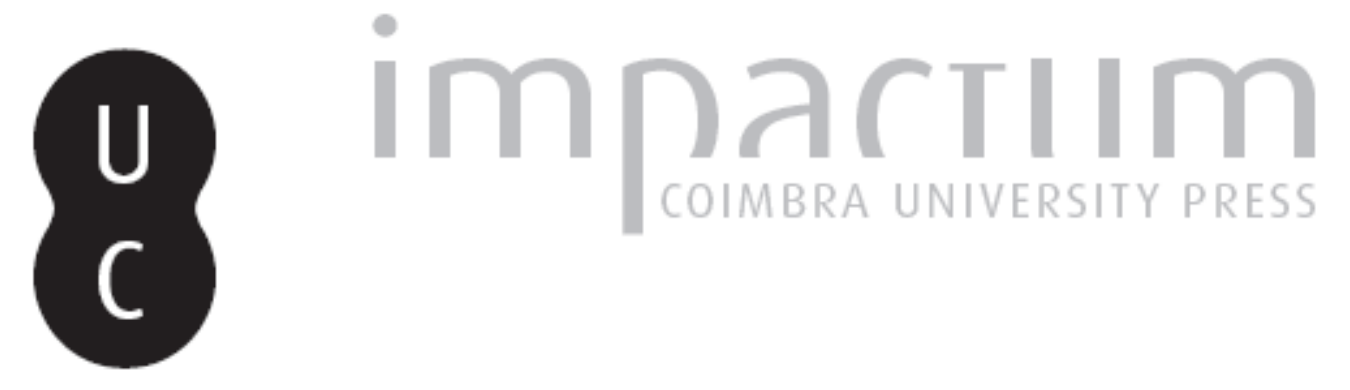

\title{
A comparative insight into Nicolae Ceauescu's strategies of power consolidation
}

\section{Autor(es): Stanciu, Cezar}

Publicado por: Imprensa da Universidade de Coimbra

URL persistente:

URI:http://hdl.handle.net/10316.2/35427

DOI:

DOI:http://dx.doi.org/10.14195/0870-4147_45_18

Accessed : $\quad$ 26-Apr-2023 13:16:03

A navegação consulta e descarregamento dos títulos inseridos nas Bibliotecas Digitais UC Digitalis, UC Pombalina e UC Impactum, pressupõem a aceitação plena e sem reservas dos Termos e Condições de Uso destas Bibliotecas Digitais, disponíveis em https://digitalis.uc.pt/pt-pt/termos.

Conforme exposto nos referidos Termos e Condições de Uso, o descarregamento de títulos de acesso restrito requer uma licença válida de autorização devendo o utilizador aceder ao(s) documento(s) a partir de um endereço de IP da instituição detentora da supramencionada licença.

Ao utilizador é apenas permitido o descarregamento para uso pessoal, pelo que o emprego do(s) título(s) descarregado(s) para outro fim, designadamente comercial, carece de autorização do respetivo autor ou editor da obra.

Na medida em que todas as obras da UC Digitalis se encontram protegidas pelo Código do Direito de Autor e Direitos Conexos e demais legislação aplicável, toda a cópia, parcial ou total, deste documento, nos casos em que é legalmente admitida, deverá conter ou fazer-se acompanhar por este aviso.

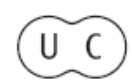




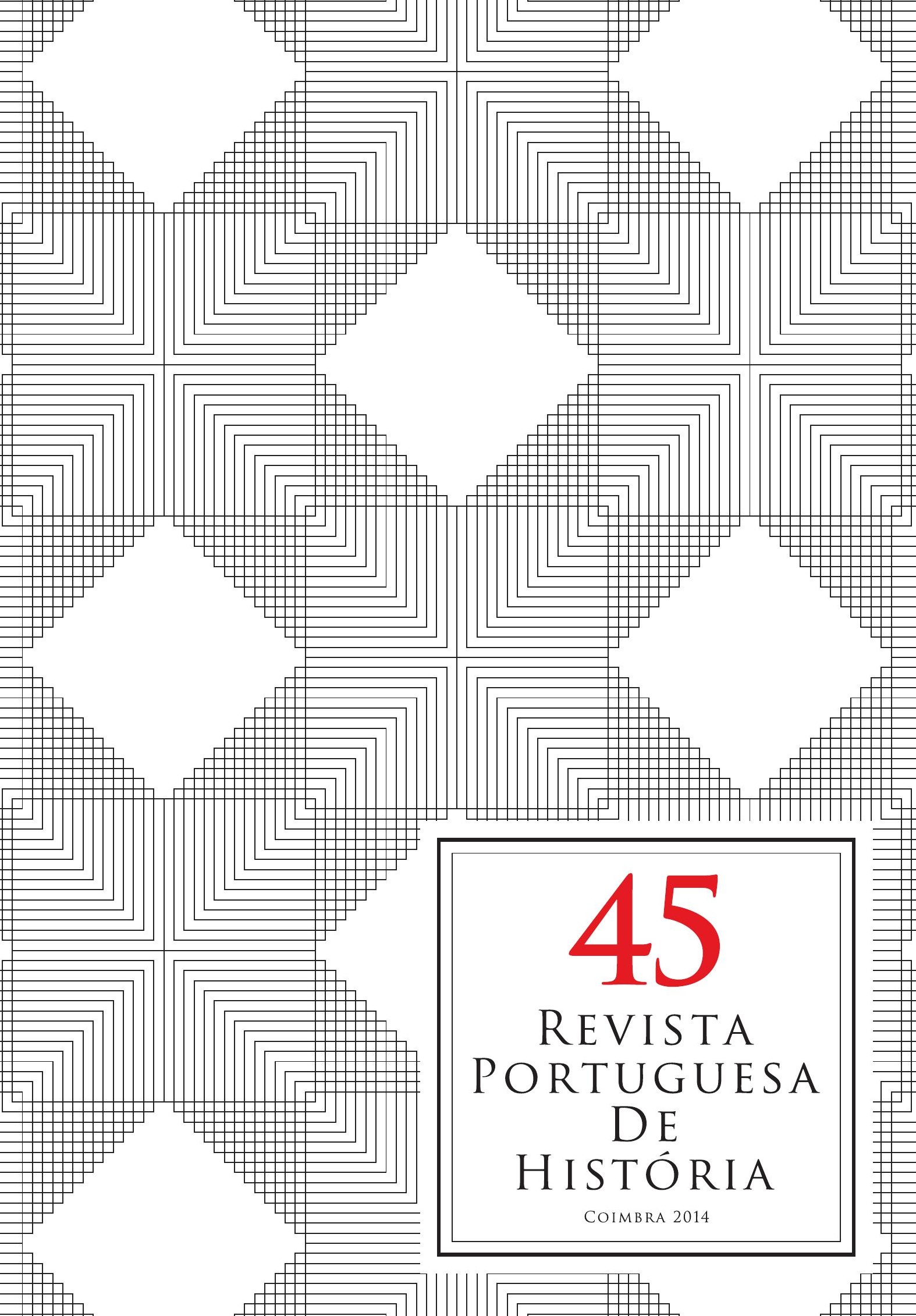




\title{
A Comparative Insight into Nicolae Ceauşescu's Strategies of Power Consolidation
}

\author{
Cezar Stanciu \\ Assistant Professor at Valahia University of Târgovişte \\ Department of History, Faculty of Humanities, University Valahia. \\ cezar.stanciu@centrulgafencu.ro; cezar_stanciu2003@yahoo.com
}

\section{Resumo:}

A sucessão do poder nos regimes comunistas afigurou-se um processo periclitante visto que não existia nenhum mecanismo constitucional disponível, sendo a tarefa que se revelou ser mais complexa a do controlo da polícia política. Os partidos comunistas confiavam fortemente na repressão política para manter o poder, mas o controlo que detinham sobre a polícia secreta era por vezes precário. Pouco tempo depois da sua subida ao poder, em 1965, Nicolae Ceaușescu da Roménia sentia que o aparelho dos assuntos internos fugia ao seu controlo, ao mesmo tempo que acreditava que só detendo um controlo total poderia verdadeiramente consolidar o seu poder. Com o intuito de alcançar o controlo que pretendia, Ceaușescu manipulou com êxito um discurso reformista que o tornou bastante popular entre os romenos, por detrás do qual travou uma dura batalha para controlar a polícia política. Sob esta máscara reformista, Ceaușescu levou a cabo reorganizações institucionais e reformas políticas com vista a eliminar qualquer movimento de resistência ao seu governo, tanto no seio do partido como nos assuntos internos. Este facto demonstra que, no seu entender, o controlo pessoal sobre a polícia política constituía um dos mais importantes instrumentos de consolidação do poder.
Abstract:

Power succession under Communist regimes was a perilous affair since there was no constitutional mechanism available and the most complicated task was control over the political police. Communist parties relied heavily on political repression to maintain power, but their control over the secret police was sometimes unstable. Soon after his power accession in 1965, Nicolae Ceaușescu of Romania perceived the internal affairs apparatus to be escaping his control, while realizing that only full control over it could really consolidate his power. In order to achieve the control he envisaged, Ceaușescu successfully manipulated a reformist discourse which made him very popular among Romanians, behind which he carried a fierce battle to control the political police. Institutional reorganizations and political rehabilitations were employed by Ceaușescu under the reformist disguise in order to eliminate any résistance to his rule, both in the party and the internal affairs. This proves that personal control over the political police was in his vision one of the most important instruments of power consolidation.

Keywords:

Romania; Communism; political police; reform; rehabilitation; power consolidation.

Palavras chave:

Roménia; Comunismo; polícia política; reformas; reorganização; consolidação do poder. 
Political repression was certainly a common feature of all Communist regimes in Eastern Europe, since their very establishment and until their collapse in 1989. The issue had often been discussed with much emotion by public and media, given its sensitive nature and the fact that many of its victims survived the changes of 1989 . This was more so valid in a country such as Romania, where political repression had reached one of its peaks during the late 1980s, when most East European societies were experiencing the relaxation of perestroika. Although Communist regimes were usually associated with repression, the relations between the political police and the party leadership under Communism had sometimes been vacillating.

This statement is valid including for Romania, usually known for the abruptness of its political police. During the late 1980s, Communist dictator Nicolae Ceauşescu largely employed the services of the Romanian political police, the Securitate, in order to control a society that was being subjected to great shortages due to economic failures. But Ceaussescu's relation with the Securitate had not always been so cordial. When he gained power in March 1965, Nicolae Ceauşescu had little control over the Internal Affairs apparatus, which was in the hands of his opponent, Alexandru Drăghici.

The basic aim of this study is to reassess the complicated relation between Nicolae Ceauşescu and the Securitate and also the role played by the political police in Ceauşescu's struggle to consolidate his power. In doing so, the analysis shall follow the conclusions enunciated in two major studies dedicated to Ceauşescu's relation with the Securitate, signed by Mary Ellen Fischer and Dennis Deletant ${ }^{1}$. This article shall engage topics such as Ceauşescu's control over the Internal Affairs apparatus as an instrument of power consolidation in a three-leveled analysis, institutional, rhetorical and political, relying on party documents, declassified in recent years. The study shall also draw comparative conclusions, based on the emerging literature on party-police relations in other countries of the Communist bloc.

It is widely known that, when Gheorghe Gheorghiu-Dej unexpectedly died in March 1965, Nicolae Ceauşescu was not one of the favorites in the struggle for succession - or, at least, he had not been, shortly before the event. There was an "old guard" around Gheorghiu-Dej, from whose members the successor was expected to be elected. According to memoirs of those directly involved in the events surrounding his death, Gheorghiu-Dej expressed pref-

\footnotetext{
${ }^{1}$ Mary Ellen Fischer, Nicolae Ceaușescu. A Study in Political Leadership (Boulder and London: Lynne Rienner Publishers, 1989); Dennis Deletant, Ceaușescu and the Securitate. Coercion and Dissent in Romania, 1965-1989 (M.E. Sharpe, 1995).
} 
erence for either Ion Gheorghe Maurer or Gheorghe Apostol, two of his most trusted companions. Still, two of the youngest members of the Political Bureau, Nicolae Ceauşescu and Alexandru Drăghici, opposed the election of a new party leader while Gheorghiu-Dej was still alive.

Soon after his death, Ion Gheorghe Maurer proposed Nicolae Ceauşescu as party leader and everyone else accepted. As both Dennis Deletant and Vladimir Tismăneanu argued, it was Maurer's way of preventing Apostol's accession and the result of an agreement between those involved ${ }^{2}$. French author Pierre du Bois defended a similar point of view in a book dedicated to Ceauşescu's accession to power ${ }^{3}$. Maurer himself was offered the position by Gheorghiu-Dej but declined it - a version which he stated in interviews and which is widely accepted by historians ${ }^{4}$. Maurer remained prime-minister (for many years to come) and another member of the "old guard" became President of the Council of State. It seemed that most of the Politburo members have shared positions and privileges at Gheorghe Apostol's expense. The other "youngster" of the Politburo, must have been excluded due to the position he previously held: minister of interior affairs - and therefore, chief of the Securitate.

Alexandru Drăghici’s image, as organizer of political repressions, was not convenient for a party that, in the context of its conflict with Moscow over development and industrialization, fought hard to gain public support ${ }^{5}$. But the reasons for which Drăghici was excluded from succession were the very reasons for which Ceauşescu disliked him most. Both Ceauşescu and Drăghici were promoted in the Politburo by Gheorghiu-Dej, shortly after the purge of Ana Pauker and her associates in 1952. On that occasion, Alexandru Drăghici became minister of internal affairs, replacing Teohari Georgescu, a close associate of Ana Pauker ${ }^{6}$. After that, he continued to remain Gheorghiu-Dej's top man when it came to police issues, either as minister of state security, minister of internal affairs or chief of Securitate ${ }^{7}$.

${ }^{2}$ Dennis Deletant, Romania under Communist rule (Civic Academy Foundation, 1998), 149-150; Vladimir Tismăneanu, Stalinism for all seasons. A political history of Romanian Communism (University of California Press, 2003), 185-186.

${ }^{3}$ Pierre du Bois, Ceaușescu la putere. Anchetă asupra unei ascensiuni politice (București: Humanitas, 2008), 87.

${ }^{4}$ Lavinia Betea, Maurer și lumea de ieri (Cluj-Napoca: Editura Dacia, 2001), 206-209.

${ }^{5}$ Tismăneanu, op. cit., 186.

${ }^{6}$ Robert Levy, Ana Pauker: The Rise and Fall of a Jewish Communist (University of California Press, 2001), 194-220.

${ }^{7}$ Membrii CC al PCR 1945-1989 (București: Editura Enciclopedică, 2004), 231. 
Ceauşescu, on the other hand, after he occupied various political positions in the army or agriculture, made a carrier as responsible for the cadres sector. When he became prime-secretary of PCR (Romanian Communist Party), his position at the top was rather vulnerable, especially since Alexandru Drăghici was still in control of the internal affairs and the Securitate. Also, the Politburo was dominated by men with much more influence than himself, veterans of party leadership whom saw nothing more in him than a "youngster". Very soon, Ceauşescu was going to change that, by clever and cunning means, staging a reform that was only directed at reducing the power and influence of everyone he perceived as adversary. Alexandru Drăghici was the prime target.

\section{Phase One: Institutional Reorganization}

As Tismăneanu emphasized, the Ninth Congress of PCR was going to become the founding myth of Ceauşescu's rule ${ }^{8}$. Gheorghiu-Dej dominated the party leadership for many years and, like in the case of Stalin's death, the keywords after the patriarch's death were "collective leadership". Ceauşescu used that in his own favor. Gheorghiu-Dej died in March 1965 and the Ninth Congress convened only months later, in July 1965. Ceauşescu saw it as an opportunity to consolidate his power, not by asserting his authority at first but by sabotaging the influence of the adversaries.

The party leadership was reorganized by replacing the old Political Bureau with an Executive Committee, much larger as number of members, which allowed him to promote some of his collaborators in the body, therefore reducing the influence of the elders. Another instrument for reaching the same goal was to superpose a Permanent Presidium over the Executive Committee, as a body in charged with handling current affairs ${ }^{9}$. A new party status was elaborated too. The most striking change was that it prohibited any person from occupying leadership position at both party and state levels ${ }^{10}$. Accumulation of party and state offices was an important instrument of influence and Ceauşescu was aiming for the same thing but, for starters, the change did not serve Ceauşescu's own power aspirations but it served to undermine the veterans' influence. This was the first strike against Drăghici.

\footnotetext{
${ }^{8}$ Tismăneanu, op. cit., 197.

${ }^{9}$ Alina Tudor-Pavelescu, 'Succesiunea lui Gheorghiu-Dej: tehnicile de transfer al puterii 1965-1969', Arhivele totalitarismului, 1-2 (2004), 120-121.

${ }^{10}$ Mary Ellen Fischer, op. cit., 79.
} 
As member of both the Executive Committee and the Permanent Presidium, Alexandru Drăghici had to choose between party leadership and his position at internal affairs. Since the nature of the regime dictated that all decision was made at party level, Drăghici decided to give up leadership of the ministry in exchange for remaining a member of party leading structures. At the time, his decision seemed wise, but it nevertheless left him with no power base. It was not only Drăghici's case, but as future would prove, he was headed for becoming Ceauşescu's first and most important victim. There is no direct proof that Ceauşescu felt threatened by Drăghici, although their rivalry was known and Vladimir Tismăneanu considered it as "fierce" course of events demonstrated that, above anybody else, Ceauşescu's efforts to build a strong power base were directed against Drăghici personally.

One of the most important features of Ceauşescu's policies was reformism, either substantiated or rhetorical. Reform, in his view, involved the consolidation of the party's position at all level of society and administration, somehow suggesting that PCR's role had been weakened in the previous years. As he was promoting reform, opposing the "new" against the "old", everything related to the "old" - all negative features and values - were blamed upon the absence of party coordination. In relation to the Securitate, Ceauşescu promoted the same approach too, but with great caution.

The activity of the internal affairs was discussed in a Plenary of the Central Committee, in June $1967^{12}$. Ceauşescu's main purpose was not very clear at the time, but it became evident soon after. The main topic was party control over the Securitate and internal affairs. The Plenary discussed the activity of the Ministry of Internal Affairs (MAI) in what appeared to be a routine analysis of a ministry's activity, though it was anything but. The Plenary adopted a Resolution on the results of the analysis, calling for measures aimed at consolidating party control over that sphere of activity, but nothing much was published in the press about it.

The content of the Resolution, according to Central Committee Chancellery records, was only finalized about a month later and is conclusive in what concerned the purposes of the meeting. The Resolution stated clearly that party committees "control and guide" the activity of the Securitate and the

\footnotetext{
${ }^{11}$ Vladimir Tismăneanu, op. cit., 185.

${ }^{12}$ Cristian Troncotă, 'Noua politică în domeniul instituției Securității regimului communist din România 1965-1989’, Arhivele totalitarismului, 3-4 (2001), 113.
} 
Ministry of Internal Affairs ${ }^{13}$. Furthermore, party committees had the responsibility to engage in periodical analysis of the activity of the above-mentioned organs while the chiefs responsible from MAI and Securitate were demanded to submit periodical reports on their work to local party organizations. The Resolution also insisted that the political education of MAI and Securitate cadres had to be improved, under supervision from party organizations ${ }^{14}$.

Another important part of the Resolution concerned party members. The Central Committee decided that party members could not be enlisted as "collaborators" of the political police without the express consent of the organization to which he or she belonged. Also, party members with leading positions (secretaries of organizations and committees) could not be used in "informative" work at all. Furthermore, investigation of party members by MAI or Securitate organs was only permitted with the approval and consent of party organizations ${ }^{15}$. A clear difference was established this way between PCR members and other citizens. It was also evident that the Resolution intended to transmit a sheer message that party organs were above Securitate and that the political police was nothing but an instrument of the party - a concept that Ceauşescu was going to repeat on various occasions. Did he feel, at that time, that it was not?

The issue of party-police relations was very complicated under Communist regimes, since the relation fluctuated in its meaning and content according to specific conditions in each country. A conflict between the party and the police first manifested in the Soviet Union, shortly after Stalin's death. Stalin strengthened his control over the political police by means of purges, but Lavrenti Beria's influence scared the collective leadership which made it a priority to get rid of him. Even after Beria's purge, the party leadership perceived a threat from the political police and, as Mikhail Tsypkin argued, tried to impose control over the institution by breaking it apart into two bodies: the Ministry of Internal Affairs (MVD) and the political police, downgraded to a simple "committee" (KGB), after having been a ministry. Also, MVD and

${ }^{13}$ Hotărîre. Strict secret [Resolution. Strictly classified], in National Historical Archives of Romania (onwards: ANIC), fund CC al PCR, section Chancellery, dossier no. 115/1967, 113.

14 ibid., 114, 118. The document was published in: Monica Grigore, "Ceauşescu şi redefinirea raporturilor dintre partid şi securitate (1967-1968)", in Silviu Moldovan, ed., Arhivele Securităţii, vol. I (București: Nemira, 2004), 414-420.

15 ibid., 115-116. On the reform of the Securitate in 1967, see the consistent volume of documents: Florica Dobre, ed., Securitatea. Structuri/cadre, obiective și metode 1967-1989 (București: Editura Enciclopedică, 2006), 13-19 et passim. 
KGB organs were demanded to report to party organs on their activity and were also forbidden from spying on party members ${ }^{16}$.

After Nikita Khrushchev's demise, though, the political police regained significance, since it had been directly involved in the plot. The new party leader, Leonid Brezhnev, had many challenges to deal with and he increasingly relied on the KGB. But the evolutions in Romania in 1965-1967 do not resemble the Brezhnev-Khrushchev succession, in which the KGB participated, but seem to resemble the Khrushchev-Stalin succession, when party and police were in conflict. Alexandru Drăghici did not oppose Ceauşescu's accession to power explicitly but was perceived as a threat due to his control over Securitate, similarly to the way Khrushchev (and the other members of the "collective leadership") feared Beria.

Party-police relations were settled in the same context in East Germany, too. The Berlin workers' riot in 1953 imposed serious reassessment of Stasi activity and on that occasion Stasi organs were forbidden from mounting operations against party members. Still, a break of Khrushchev-Beria or Ceauşescu-Drăghici kind did not occur. There was a party organization inside Stasi led by a general with a veto right in what concerned personnel and especially promotion, which granted him great authority. Also, when the UlbrichtHonecker succession occurred in 1971, no such division appeared since Erich Honecker had been Central Committee secretary in charged with supervising Stasi and had sufficient knowledge and influence in the institution ${ }^{17}$.

The rivalry between Ceauşescu and Drăghici caused a break between party leadership and the political police which can account for the emphasis laid on the party's role and position by Ceauşescu. In late July 1967, the Executive Committee discussed the Central Committee Resolution again, which indicates that it had not achieved a final form by that time, although a month had passed since the Central Committee Plenum ${ }^{18}$. Discussions focused on the relation between party members and MAI. Both Ceauşescu and premier Maurer insisted that it was unacceptable for a party member to be investigated and

\footnotetext{
${ }^{16}$ Mikhail Typskin, 'Terrorism's Threat to New Democracies. The Case of Russia', in Thomas Charles Bruneau, Steven C. Boraz, eds., Reforming Intelligence: Obstacles to Democratic Control and Effectiveness (University of Texas Press, 2007), 271-272. Among the charges brought against Beria was that he tried to subordinate the party to police organs. See: Sidney I. Ploss, The Roots of Perestroika: The Soviet Breakdown in Historical Context (McFarland, 2010), 85-86.

${ }^{17}$ John C. Schmeidel, Stasi: Sword and Shield of the Party (Taylor\&Francis, 2008), 14-15.

${ }^{18}$ Stenograma ședinței Comitetului Executiv al CC al PCR din ziua de 27 iulie 1967 [Stenograph of the meeting of the Executive Committee of the CC of PCR which took place on 27 July 1967], in ANIC, fund CC al PCR, section Chancellery, dossier no. 115/1967, 12.
} 
condemned by judicial organs. Party organizations, Ceauşescu stated, have to pronounce their decision before judicial organs and, in order to do that, party organizations have to be informed by legal investigators about any procedure initiated against a party member. In that case, the guilt must first be established by the party, which has to exclude that person from its members. Only after the exclusion, could the suspect be presented in front a court of law ${ }^{19}$.

The debates reveal how important it was for the party leadership to assert the superiority of party membership in front of MAI or Securitate organs, the only responsible for criminal investigations. At the time, it was not visible that the initiative was manifestation of a power struggle although Ceauşescu was in control of the party and Alexandru Drăghici still had significant influence over MAI and Securitate. Their "fierce rivalry" remained discreet until spring 1968. But in the same summer of 1967, a series of decisions were also made which completely reorganized the entire structure of control over internal affairs.

It is very difficult to establish just how influential was Alexandru Drăghici in the internal affairs apparatus, but given the fact that he had been in charge of it - on different position - for over 13 years - it is reasonable to presume that his influence was indeed strong. Dennis Deletant also mentioned in his study that Drăghici was the only Politburo member not to vote in favor of Ceauşescu in March 1965, but abstained ${ }^{20}$. Ceauşescu too perceived him as an opponent. His struggle to control the internal affairs consisted of two steps: the first was aimed at destroying the power base of the adversary and only the second was aimed at installing his own control. The reorganization of the internal affairs apparatus in the summer of 1967 represented only the first step.

The key words when it came to change were - just as in the case of the party - reform and collective leadership. In order to reduce the influence of one, he imposed the control of many. The Department of State Security was going to act as an independent body inside the Ministry of Internal Affairs. The Securitate, according to the decisions elaborated or attributed to the Central Committee Plenum, was placed under the control of the Council of State Security, a collective organ, led by a President that was going to be first deputy of the minister of internal affairs. Also, when it came to the rest of the minis-

\footnotetext{
19 ibid., 14.

${ }^{20}$ Deletant, Ceaușescu and the Securitate..., 71.
} 
try, a Board of MAI was established with the task of supervising the activity of leading structures of the ministry ${ }^{21}$.

Dissipating authority in collective bodies was Ceauşescu's strategy to facilitate the imposition of his own control. The Permanent Presidium of the Central Committee approved the reorganization on 14 July 1967 and on the same day Ion Stănescu was appointed as president of the Council of State Security ${ }^{22}$. Stănescu's appointment was surprising especially because he had virtually no experience in the internal affairs apparatus; he was only member of a Central Committee section responsible for supervising MAI but was a party man by excellence. At the Ninth Congress in July 1965, Ceauşescu promoted him as member of the Central Committee and, at the time of his appointment in front of the Securitate, he was only prime-secretary of a regional party committee ${ }^{23}$.

In her study dedicated to Ceauşescu, Mary Ellen Fischer was of the opinion that creation of the Council of State Security was a compromise in its essence, between Ceauşescu's need for party control and the reticence of the MAI apparatus. The Council, as the author remarked, was responsible in front of the government and the party, as if it was an independent body, but it nonetheless remained institutionally subordinated to $\mathrm{MAI}^{24}$. The ultimate purpose of this reorganization, as Dennis Deletant noticed, was to remove the Securitate from MAI control and place it under party control instead, i.e. Ceauşescu's own control ${ }^{25}$.

The reorganization continued less than a year after. Towards the end of 1967, Ceauşescu became president of the Council of State replacing Chivu Stoica, in spite the initial commitment in favor of "collective leadership" From that position, in April 1968 Ceauşescu issued a Decree which removed the Council of State Security from MAI and established it as an independent body, confirming at the same time Ion Stănescu's presidency ${ }^{27}$. At that point,

${ }^{21}$ Protocol nr. 39 al ședinței Prezidiului Permanent al CC al PCR din ziua de 14 iulie 1967 [Protocol no. 39 of the meeting of the Permanent Presidium of CC of PCR which took place on 14 July 1967], ANIC, fund CC al PCR, section Chancellery, dossier no. 110/1967, 3.

22 ibid., 4.

${ }^{23}$ Membrii CC al PCR..., 545.

${ }^{24}$ Mary Ellen Fischer, op. cit., 105.

${ }^{25}$ Deletant, Ceaușescu and the Securitate..., 74.

${ }^{26}$ Alina Tudor-Pavelescu, op. cit., 123.

${ }^{27}$ Well-documented studies on these issues were published by Florian Banu. See for example: Florian Banu, ,, Un deceniu de împliniri măreţe”. Evoluţia instituţională a Securităţii în perioada 1948-1958 (Iaşi: TipoMoldova, 2010); Florian Banu, Luminiţa Banu, Partidul şi Securitatea. Istoria unei idile eşuate 1948-1989 (Iaşi: Demiurg, 2013). 
Ceauşescu's position was certainly much stronger and allowed him to prepare his final and fatal strike against Alexandru Drăghici.

\section{Side-faces of the Reformist Discourse}

Nicolae Ceauşescu's assault on the Securitate and Alexandru Drăghici was greatly facilitated by his manipulation of a reformist rhetoric which brought him great popularity. His struggle for control was disguised behind what seemed as a coherent reform program, depicting him as the man of the "new" fighting against the "old". He fostered what Vladimir Tismăneanu called the "first genuine thaw in postwar Romania" by encouraging diversity in artistic expressions, blaming the rigid forms of "socialist realism" and calling for active participation of the masses in the decision-making process through party committees ${ }^{28}$. He changed the name of both the party and the country and insisted on strict observance of "socialist legality" by all state institutions, as it was stated in a new Constitution adopted in $1965^{29}$.

In a recent study on Soviet politics, author Graeme Gill noticed that, shortly after Stalin's death, Nikita Khrushchev tried to display a different "leadership style", active and energetic as opposed to Stalin's contemplative stance in political life. Khrushchev visited as many factories and villages as he could, talked to people, portraying himself as a "praktik" rather than an intellectual ${ }^{30}$. That was precisely what Ceauşescu did. Without any inhibition, Ceauşescu visited numerous cities, participated in meetings with various professional categories and, above all, writers and intellectuals, talking of reforms and change, emphasizing the need to adapt to the "new" as the "old" no longer corresponded to social conditions in Romania. His predecessor GheorghiuDej was not very fond of such visits and endless speeches, but Ceauşescu's energy did not seem to have limits.

The fact that the reformist discourse was only a strategy of power consolidation rather than a real reform program is clearly demonstrated by the fact that at no point was the leading role of the party subjected to question. PCR reserved the right to a "monopolistic interpretation" of Marxism-Leninism, as

${ }^{28}$ Vladimir Tismăneanu, op. cit., 192.

${ }^{29}$ Deletant, Ceaușescu and the Securitate..., 71.

${ }^{30}$ Graeme Gill, Symbols and Legitimacy in Soviet Politics (Cambridge University Press, 2011), 170 . 
Tismăneanu and Bogdan Iacob emphasized in another study ${ }^{31}$. In other words, it was a "top to bottom", strictly controlled, reformation process, in which open debate and criticism were only acceptable inside party and within the limits prescribed by the party.

Czechoslovakia is a good example in terms of comparisons because its evolution in the period preceding the "Prague spring" represented the exact opposite. In Oldřich Tůma's words, the party in Czechoslovakia was confronted with a real crisis of the regime, due to the fact that party leadership failed to implement any kind of reforms in the context of de-Stalinization. There were forces in Czechoslovak society asking for many more liberties than the party was willing to accept, forces that engaged in open debates and discussions, involving mostly students and intellectuals, but not only ${ }^{32}$. It was therefore a "bottom to top" movement that the party eventually failed to control.

PCR did not have to deal with such a situation in spite the fact that it eluded de-Stalinization too. Confronted with the perils of de-Stalinization, Gheorghiu-Dej discovered that national identity could be a very useful political resource and manipulated it in order to insure his political survival. NationalCommunism was practically Gheorghiu-Dej's response to de-Stalinization and he tried to place the party in the historical continuity of the Romanian medieval principalities, as Dragoș Petrescu argued, by carefully manipulating history ${ }^{33}$. Depicting himself as a defender of the country's interests in front of a hegemonic Soviet Union and preserver of national values, Gheorghiu-Dej managed to gain considerable public support. This also served as a safety valve for social pressures, as it diverted attention from other pressing issues such as the absence of liberties.

Nicolae Ceauşescu inherited this situation and took advantage of it. Gheorghiu-Dej tried to make a connection between the Communist party and the Romanian history, in which the party was the defender of Romanian national interests and values. It was in that meaning that Ceauşescu asserted the supremacy and leading role of the party. Still, he took things one step further by bringing back - even if merely as suggestion - the abuses of the Stalinist

${ }^{31}$ Vladimir Tismăneanu, Bogdan Iacob, 'Betrayed Promises: Nicolae Ceaușescu, the Romanian Communist Party, and the Crisis of 1968', in Vladimir Tismăneanu, ed., Promises of 1968: crisis, illusion, and utopia (Budapest: Central European University Press, 2011), 273-274.

32 Oldřich Tůma, 'Reforms in the Communist Party: the Prague Spring and Apprehension about a Soviet Invasion', in Gnther Bischof, Stefan Karner, Peter Ruggenthaler, eds., The Prague Spring and the Warsaw Pact Invasion of Czechoslovakia (Rowman\&Littlefield, 2010), 62-63.

${ }_{33}$ Dragoș Petrescu, 'Building the Nation, Instrumentalizing Nationalism: Revisiting Romanian National Communism, 1956-1989, Nationalities Papers, 37, 4 (2009), 523-524. 
era. He tried to dissociate between party and its former leader. The meaning of his approach was that the party was indeed the sole defender of Romanian national interests but the past abuses are to be blamed only on Gheorghiu-Dej. The charismatic legitimacy previously invested in the leader was being transferred back to the party - it was an observation noted by Graeme Gill in reference to Khrushchev's succession of Stalin ${ }^{34}$. It goes perfectly for Ceauşescu, as well.

Ceauşescu blamed the leader in order to save the party and therefore himself. His speeches of the period 1965-1968 are characterized by two basic features: on one hand, emphasis on the leading role of the party, on the need to consolidate unity around party leadership as well as party guidance in all fields of activity, and, on the other hand, emphasis on the need to overcome past mistakes, to prevent abuses and denounce the rigid methods of the previous decades. The party was good, but its leader was bad, was the message he was trying to convey. It should only become evident one year later.

As for his relation with the Securitate, these ambivalences of the reformist discourse are all present in a famous speech delivered by Ceauşescu in July 1967, at a meeting with the MAI cadres. It was by far the most important discourse on reform and departure from the past that he had delivered up to that point. After the Central Committee Plenum that debated the activity of the MAI, it was decided that the decisions made on that occasion be popularized and debated with the party activists. Ceauşescu deliberately assumed the responsibility of presenting the resolutions in front of MAI cadres. Was he trying to show everybody who the boss was?

After praising the work done by MAI in helping to promote construction of socialism, Ceauşescu engaged in sharp criticism of past mistakes. He insisted upon the fact that numerous abuses and mistakes had been done in the past due to wrong interpretation of facts. Such misdeeds were directed against party and state activists, too, he said. Furthermore, there was a tendency of minimizing the abuses of the past, which had to be fought against. In the past, Ceauşescu explained, there were distinct attempts from MAI and Securitate to evade party control, as these institutions perceived themselves as bastions separate from the party. The rules of conspiracy, specific to their field of activity, Ceauşescu thundered from the tribune, do not and cannot justify such attempts ${ }^{35}$.

${ }^{34}$ Graeme Gill, op. cit., 164.

${ }^{35}$ Nicolae Ceaușescu, Cuvîntare la consfătuirea cu activul de bază al Ministerului Afacerilor Interne 18 iulie 1967 (București: Editura Politică, 1967), 13-15. 
Next, Ceauşescu tried to formulate the future priorities of the institutions, in the same reformist terms. In his view, the target of MAI activity had changed along with the progresses achieved in socialist construction. As the domestic class enemies had been destroyed or assimilated, the suspicion with which the Securitate regarded most of the population was no longer justified ${ }^{36}$. The country was at a crossover of epochs, he was suggesting, in which the priorities of the future must be formulated in different terms, having under consideration the progress achieved.

The Securitate organs must change their focus, Ceauşescu stated, from the domestic class enemy, which was the adversary of the past, to the espionage activities employed by foreign governments. Foreign espionage was trying to recruit "decomposed elements" in order to sabotage the construction of socialism and security had to be redefined in terms of state interests ${ }^{37}$. Again, the national(ist) component of Romanian Communism is visible. As for the working class in Romania, Ceauşescu declared that Securitate organs must be able to distinguish between constructive criticism, which is not in contradiction with socialism, and malevolent criticism, directed and encouraged by foreign espionage.

His fight to assume control over the political police consists of very unusual associations of patriotic/nationalistic rhetoric with liberal stands, simulating support for civil liberties. In the creation of the Ceauşescu myth, one understood exactly what one expected, for his discourse was sufficiently multivalent as to encourage a multitude of interpretations. The conclusion of the speech he delivered to MAI cadres was that the ministry and the Securitate must assume the past in a self-critical manner and reform themselves under party guidance. Only party control and supervision, he concluded, were guarantees against further abuses ${ }^{38}$. In other words, he stressed the fact that abuses were not to be blamed on the party, but they were committed especially because the organs escaped party control. Except from Gheorghiu-Dej, another person was discreetly dissociated from the party: Alexandru Drăghici. If the party was not responsible for abuses, then people must be - and who was in charge of the Securitate during Gheorghiu-Dej's time?

At the time, discussions did not go further. Ceauşescu took his time to reorganize the institutional structure of MAI and was busy separating the Securitate from the rest of the ministry, in order to make them both easier to control.

\footnotetext{
${ }^{36}$ ibid., 15 .

${ }^{37}$ ibid., 16-17.

38 ibid., 20.
} 
But he had an ace in his sleeve that most people did not know about. As these changes were happening, a small commission was silently working its way through the party archives, preparing the Romanian equivalent of Khrushchev's Secret Report of 1956.

\section{The Second Death of Gheorghiu-Dej}

Lucrețiu Pătrășcanu had been what one may call a romantic Communist. Of a good social background, lawyer and philosopher, Pătrășcanu joined the party from pure belief and after the war had the chance to play a rather prominent role in the party's ascension to power. His public popularity and charisma though were not regarded as qualities neither by Gheorghiu-Dej nor by his competitor Ana Pauker. After the denunciation of the "Titoist deviation" in 1948, Pătrășcanu was arrested and investigated for various accounts having to do with betrayal and espionage. Gheorghiu-Dej finally decided to get rid of him in the aftermath of Stalin's death, when he probably thought that Khrushchev was looking for a potential replacement in the Romanian party leadership. Lucrețiu Pătrăşcanu was tried and executed in 1954, closing a rather long and embarrassing episode in the party's history. In April 1968, he was going to become Ceauşescu's ace in the sleeve. ${ }^{39}$

Pătrășcanu's investigation and subsequent assassination was directed by Alexandru Drăghici and Ceauşescu saw a reinvestigation of the case and potential rehabilitation as a weapon to use against both the living Drăghici and the dead Gheorghiu-Dej. The party commission worked discreetly for over two years and its report was presented at the Central Committee Plenum which convened in April 1968. The report was overwhelming in its content and significance because it depicted Gheorghiu-Dej as a merciless criminal together with Drăghici. Gheorghiu-Dej's memory seemed silently to fade away very soon after his death, but no one had dared speak up against him in any way, until that moment. As for Lucrețiu Pătrăşcanu, he was a taboo case given the fact that most members of the party leadership had also been Politburo members at the time of his execution and approved of the decision.

After reviewing all the accusations brought against Lucrețiu Pătrășcanu and the evidences which supported them, the report of the commission stated:

${ }^{39}$ Fora consistent political biography of Lucrețiu Pătrășcanu, see: Lavinia Betea, Lucrețiu Pătrășcanu. Moartea unui lider comunist, 2nd edition (București: Curtea Veche, 2006). 
The investigation, trial and condemnation of Lucrețiu Pătrăşcanu represented a monstrous frame-up both judicially, as well as politically and morally. He was arrested, investigated and sentenced with premeditation, violating the most elementary norms of legality and justice, committing an act of extreme gravity, a foul crime. None of the evidences brought in front of the court to prove Lucretiu Pătrăşcanu's guilt referred to real deeds, that he may have committed, but were gross-minded figments, devised on bases on false statements, drawn out by means of physical and moral coercion from some of the defendants or from the witnesses..$^{40}$

The report referred largely to Gheorghiu-Dej's personal involvement in the investigation, to the way he overviewed the statements of the witnesses and gave instructions on how they should be questioned and also compiled a list of those responsible for the assassination, consisting of many high-profile officers from the Securitate. In the period of reference, the report also stated, there was a general climate of abuse and illegality caused - among other factors - by the absence of party control over the internal affairs apparatus ${ }^{41}$.

The report was a strong weapon directed towards three targets: (1) Gheorghiu-Dej, whose prestige was ruined and that permitted Ceauşescu to impose his own personality as a restaurateur of legality and Leninist norms, (2) the veterans of the party, all involved in a certain measure in Pătrăşcanu's assassination, if only by passive consent and (3) Alexandru Drăghici, personally involved in the investigation of the case. But when he spoke in front of the Central Committee, Ceauşescu focused his fire against Drăghici alone. Gheorghiu-Dej had no way of defending himself and his memory was already befouled. As for the veterans, Ceauşescu was probably satisfied with having the upper hand in the party leadership and did not seem keen on sacrificing them all, as long as they subdued. And they did.

Ceauşescu made it clear in his speech that removal of Alexandru Drăghici from his positions was not his only goal, but he also aimed at subordinating the Securitate. It was a misconception, he argued, that the Securitate had insured the success of socialism by fighting and defeating the class enemy. The victory in the struggle for socialism was achieved by the party, Ceauşescu reasserted, for it was the Securitate who served the party and not the other way around.

${ }^{40}$ Raportul Comisiei de Partid constituită în vederea clarificării situației lui Lucrețiu Pătrășcanu [Report of the Party Commission established in order to clarify the situation of Lucrețiu Pătrășcanu], ANIC, fund CC al PCR, section Chancellery, dossier no. 66/1968, 217.

${ }^{41}$ ibid., 221. 
It is not police repression that liquidates the class enemy, he claimed, but the revolutionary transformation of society, a task undertaken by the party ${ }^{42}$.

Apparently, Drăghici chose to go down fighting, although his experience in the system surely left him with no doubt about his political future. Drăghici tried to exculpate himself by blaming everything on the specific conditions of the time and explaining that the techniques used on Pătrășcanu, such as coercion, were common and necessary in such a field of work as that of political police. He invoked Gheorghiu-Dej's commands to justify himself that everything happened with the party's knowledge and consent.

Ceauşescu once again stood in defense of the party and accused his opponent of being a coward. It was not the Securitate or the party that committed such horrible deeds, but certain people within the party and the Securitate. He accused Drăghici of being both over-zealous and incompetent and warned him not to hide behind Gheorghiu-Dej. We can only imagine the shock of most Central Committee members when listening to the report and the exchange of words between Drăghici and Ceauşescu. The leadership was practically paralyzed and bowed down in front of Ceauşescu as it was the only thing it could do. So the Plenum voted for Alexandru Drăghici's dismissal from all his leading positions in the party.

After being rid of Drăghici, Ceauşescu continued his scenario aimed at destroying Gheorghiu-Dej's image. Further inquiries into the purge of the Ana Pauker group revealed more and more abused that had been committed under his predecessor's leadership. Ana Pauker was rehabilitated and so were other party members that had been purged along with her. The reports issued on that occasion contained - just like in Pătrăşcanu's case - lists of Securitate officers responsible for abuses and misdeeds. But when it came to investigating those responsible, Ceauşescu did not seem vindictive at all. His attitude was at best characterized by caution. This goes to prove that, one hand, Ceauşescu was not interested in doing justice, but just in consolidating his power and, on the other hand, that he was afraid it might turn the internal affairs apparatus against him. At no point did his attack on the Securitate go beyond the needs of his own control. Justice or punishment was not on his agenda.

It is not far-fetched to presume that Ceauşescu did have certain apprehension towards the internal affairs. The comparative study of other Commu-

${ }^{42}$ Expunerea tov. N. Ceaușescu la Plenara CC al PCR din 22-25 aprilie 1968 [The Speech delivered by cmd. N. Ceaușescu at the CC Plenum of 22-25 April 1968], ANIC, fund CC al PCR, section Chancellery, dossier no. 66/1968, 30-31. 
nist regimes in Eastern Europe demonstrates that political leaders have had a rather difficult time in controlling and subordinating the internal affairs and most Communist leaders seemed rather weary of the political police whom they needed and feared at the same time. In her study on Poland, Lavinia Stan pointed out that party leader Władisław Gomułka, himself of former prisoner of the political police, proved to be very prudent in his relation with the institution, in spite degrading it to a department inside the Ministry of Internal Affairs in the aftermath of the October 1956 events. It was only four years later, in 1960, that the party explicitly prohibited the political police (Sluzba Bezpieczenstwa) from recruiting informers within its ranks. But, in spite this, the institution continued to use party members for different tasks related to its field of work, even in the absence of signed pledges ${ }^{43}$.

The Soviet case is much more conclusive in this sense. Although Nikita Khrushchev employed great efforts to subordinate the KGB, he failed to reach the same level of control that Stalin previously had. Both sides seemed to agree that it was the KGB that served the party and not the other way around, still, the KGB seemed to had taken the liberty to make its own decisions in specific situations. Its officers had received Khrushchev's criticism with discontent, argued Mikhail Tsypkin, and felt that the responsibility for past abused belonged to the party itself which issued orders to that effect. It was the same argument that Drăghici tried to engage in his defense in April 1968 to no avail. Still, in 1964 the KGB supported the group led by Leonid Brezhnev in its plot to oust Khrushchev, practically betraying the acting party leader ${ }^{44}$. Surely Ceauşescu must have been aware of this.

He was also cautious when it came to disclosing Gheorghiu-Dej's abuses. Condemnation of past abuses had not been a feature of Romanian communism; when it came to de-Stalinization, Gheorghiu-Dej tried to limit it by blaming past abuses on his adversaries, especially the Pauker group and by

${ }^{43}$ Lavinia Stan, op. cit., 77.

${ }^{44}$ Mikhail Tsypkin, "Terrorism's threat to new democracies. The case of Russia”, in Thomas Charles Bruneau, Steven C. Boraz, eds., Reforming Intelligence: Obstacles to Democratic Control and Effectivness (University of Texas Press, 2007), 272.Another notorious case in which the KGB got involved in political decision making was the "Prague spring" in Czechoslovakia. In spite Brezhnev's reticence in using military instruments, the KGB deliberately controlled the flux of information in such a way as to encourage a military intervention. See: Mark Kramer, „The Prague Spring and the Soviet Invasion of Czechoslovakia: New Interpretations". Cold War International History Project Bulletin, Fall 1993, Wodrow Wilson International Center for Scholars, 7 . 
keeping the debates behind closed doors ${ }^{45}$. Ceauşescu's condemnation of the past remained within the same limits. Controlled assumption of the past was a pattern of behavior in the Communist bloc. When writing about János Kádár's handling of Hungary's Stalinist past in the aftermath of the $22^{\text {nd }}$ Congress of the CPSU (Communist Party of the Soviet Union), author Roger Gough stressed out that Kádár was especially afraid that "uncontrolled denunciation of the past could undermine the party's legitimacy"46.

The Hungarian party decided to set up a commission to investigate its Stalinist past and the abuses committed but kept the investigation very discreet. As Gough mentioned, its purpose was "restricted to reviewing court proceedings against Communists and former Social-democrats and ignoring the abuses suffered by ordinary citizens." Furthermore, János Kádár was not interested in any trial against his predecessor, Mátyás Rákosi, who bore much of the responsibility for the Stalinist crimes in Hungary ${ }^{47}$. Neither was Ceauşescu interested in a Drăghici trial, but was simply satisfied with having him removed from his positions.

The investigations continued in the months following the April 1968 Plenum with the rehabilitation of the Pauker group ${ }^{48}$. A list was compiled with Securitate officers such as Gheorghe Pintilie or Ion S,oltuțiu responsible for using methods of physical coercion against party members under investigation, but no legal measures were taken against them. The issue was discussed in a meeting of the Executive Committee on 19 September 1968 when a decision was made to investigate those officers only at party level. The party organizations to which they belonged were summoned to discuss their cases

${ }^{45}$ Dragoș Petrescu, 'Community Building and Identity Politics in Gheorghiu-Dej’s Romania (1956-1964)', in Vladimir Tismăneanu, ed., Stalinism Revisited. The Establishment of Communist Regimes in East-Central Europe (Budapest: CEU Press, 2010), 416.

${ }^{46}$ Roger Gough, A Good Comrade: János Kádár, Communism and Hungary (IB Tauris, 2006), 137. The $22^{\text {nd }}$ Congress of the CPSU which took place in 1961 was the stage for the second denunciation of Stalin's cult of personality by Nikita Khrushchev. For further details: Polly Jones, 'From the Secret Speech to the burial of Stalin: real and ideal responses to de-Stalinization', in Polly Jones, ed., The Dilemmas of De-Stalinization: Negotiating Cultural and Social Change in the Khrushchev Era (Routledge, 2006), 51.

${ }^{47}$ Roger Gough, op. cit., 135-136. Mátyás Rákosi was secretary general of the Hungarian Communist Party (1945-1956) and was known for his loyalty to Stalin and the Soviet Union, but also for the brutality of his regime. See: László Borhi, Hungary in the Cold War 1945-1956. Between the United States and the Soviet Union (Budapest: CEU Press, 2004).

${ }^{48}$ Protocol nr. 47 al ședinței Prezidiului Permanent al CC al PCR din ziua de 16 septembrie 1968 [Protocol no. 47 of the meeting of the Permanent Presidium of CC of PCR which took place on 16 September 1968], ANIC, fund CC al PCR, section Chancellery, dossier no. 153/1968, 3. 
and eventually exclude them as members. Some of the distinctions they had received in the past were withdrawn ${ }^{49}$. But there was no criminal investigation into their past and there was not much investigation into the abused done against ordinary citizens either.

As to the limits in dealing with the past - and the political content of such initiative - another interesting detail bears witness. The above-mentioned meeting of the Executive Committee discussed another issue that had been hidden from the public, a murder committed by Alexandru Drăghici in 1954. Apparently, a person that used to know Drăghici prior to his political ascension met him in a bar one night, in the city of Sibiu and approached him, perhaps not in the most courteous fashion. In unclear circumstances, Drăghici murdered that person. One member of the Executive Committee, premier Maurer, had a conclusive view on the topic. In the event of a trial, Maurer thought that:

Drăghici's defense shall reveal a series of ugly things, not only about certain practices of a certain part of the leadership during a certain period, but also the source of inspiration for these practices. The trial would take a character directed not only against some elements of the Romanian leadership, but also directed against a state that is very sensitive to this. We would have nothing to gain from this, on the contrary, we would not be able to keep the trial public, to debate it, but would have to be done in secret session and all the infamies that we are now trying to fix have been done in secret meetings $(\ldots) .^{50}$

Maurer was referring to the Soviet Union, of course. In the end, the issue was dropped and an agreement was reached to expel Drăghici from the party and that was the end of it. Once again, this proves that the entire initiative was not aimed at reformation, but only a strategy of power succession. Rehabilitating Pătrăşcanu was only an instrument to destroy Gheorghiu-Dej's image and prestige, to put the veterans under control and, finally and most important, to remove Drăghici and diminish his influence over the internal affairs appara-

\footnotetext{
${ }^{49}$ Stenograma ședinței Comitetului Executiv al CC al PCR din ziua de 19 septembrie 1968 [Stenoograph of the meeting of the Executive Committee of CC of PCR which took place on 19 september 1968], ANIC, fund CC al PCR, section Chancellery, dossier no. 156/1968, 9-13. The document was published in: Mihnea Berindei, Dorin Dobrincu, Armand Goşu, eds., Istoria comunismului din România, vol. II, Documente. Nicolae Ceauşescu (1965-1971), (Iași: Polirom 2012), 469-476.

${ }^{50}$ ibid., 14-15. In an interview published after 1989, Maurer expressed his conviction that Alexandru Drăghici was “the Russians' man". As a minister of internal affairs it could not have been otherwise, Maurer argued. See: Lavinia Betea, op. cit., 208-209.
} 
tus. The reformist discourse only served to exploit the benefits of the move in terms of popularity, by portraying Ceauşescu as reformer and defender of legality.

\section{Aftermath: the struggle goes on}

A most interesting incident occurred in 1973 which is very illustrative for the complicated relation between party leadership and the political police. In the spring of that year, a famous Romanian doctor, Abraham Schachter, committed suicide by jumping off of a hospital roof. Shortly after, the minister of internal affairs and former chief of Securitate, Ion Stănescu, was dismissed from his position and sent to do party work somewhere in the province ${ }^{51}$. Between the two events, there was a close relation: Abraham Schachter was Ceauşescu's personal doctor.

In mid March 1973, Ceauşescu summoned the entire MAI Board for a secret but explosive meeting concerning Securitate practices that came in direct conflict with party directives. Apparently Ceauşescu had found out that the Securitate had been monitoring dr. Schachter for some time and even staged provocations against him in order to establish his honesty ${ }^{52}$. Put under severe pressure as Securitate officers were swarming around him and his family, having no one to trust, the doctor chose to take his own life in desperation. Ceauşescu was outraged and decapitated the internal affairs on that occasion.

The meeting between him and the MAI Board consisted of Ceauşescu's long monologue directed against what he perceived to be insubordination on part of the internal affairs apparatus:

Today I came in possession of these documents from the Securitate, rather voluminous as you see, concerning the activity of the secretary general. It is true that, for the sake of 'conspiracy', my name appears by the initials C.N. and is handwritten. These documents concern a long period from the activity of some doctors whom have consulted me. (...) I asked cmd. Stănescu and I am asking you: for whom was such data collected: for the Americans, for the English, for the Soviets? We did not ask for such data. ${ }^{53}$

${ }^{51}$ Membrii CC al PCR..., 545.

${ }^{52}$ Stenograma ședinței de lucru cu colegiul Ministerului de Interne din 14 martie 1973 [Stenograph of the working meeting with the Board of the Ministry of Interior which took place on 14 March 1973], ANIC, fund CC of PCR, section Chancellery, dossier no. 48/1973, 3.

53 ibid. 
Ceauşescu appeared to be outraged that Securitate officers had been recruiting agents and collaborators from among his waiters and cleaning personnel. They were periodically questioned about what the secretary general was eating and what sorts of discussions took place at the table. He clearly demanded that no person working in his vicinity be recruited as collaborator of the Securitate and kept returning to the initial question about who needed such information ${ }^{54}$. The Securitate, Ceauşescu thundered, was supposed to be an organ of the party, subordinated to the party, serving the party and in no way was it permitted to verify or control the party ${ }^{55}$.

Surely, a close surveillance of the party boss was required by objective security needs and was - as still is - a common practice. But then again: Ceauşescu must have been aware of this. What was the cause of his violent reaction then? Probably the death of his personal doctor affected him in a certain measure but, according to the stenographic account of the meeting, he only referred to the issue once or twice. His primary concern was of another nature: that the Securitate appeared to escape party control, ignoring its prohibition to recruit party members, conducting secret operations directed at (not necessarily against) the party, without informing party leaders or himself personally. His long monologue does have a personal note in that Ceauşescu often returned to himself as object of surveillance. It was not only about his doctor, but about the fact that he had discovered that the Securitate kept files on him. Ceauşescu certainly did not consider that as standard, customary procedures, since he decided to dismiss the minister of internal affairs over that issue.

Those present, the dismissed minister Stănescu as well as other officials such as General Nicolae Pleșiță, chief of the Securitate division responsible for the protection of party and state leaders, had only one thing to say: they worked in good faith. In different words, they emphasized the fact that the methods were erroneous, it was indeed a violation of orders, but their work was not directed against the secretary general, but was aimed at his protection. To this author, it seems very unlikely that Ceauşescu would actually believed that the work was directed against him; rather than that, he appeared to be very concerned about his still fragile control of the internal affairs. The fact that

${ }^{54}$ Stenograma ședinței de lucru cu colegiul Ministerului de Interne și șefii direcțiilor din ziua de 15 martie 1973 [Stenograph of the working meeting with the Board of the Ministry of Interior and the chiefs of Directions which took place on 15 March 1973], ANIC, fund CC of PCR, section Chancellery, dossier no. 48/1973, 16.

55 ibid., 26. 
things were being kept from him by the Securitate who organized operations around him without his knowledge seems to have been the most upsetting conclusion he had drawn from the events. There is a distinct feeling of mistrust that transpires through his criticism:

There exists a lack of trust and an unhealthy spirit. If you have such men, that are sick - because one could not use other words to describe them - remove them from their work and send them to another work. (...) Many of you have lost their human spirit and one may no longer have a guarantee that these people are not sick. ${ }^{56}$

Ceauşescu also ordered that all documents gathered by the Securitate on himself be immediately handed over to the party. Ion Stănescu was replaced in front of MAI by Emil Bobu, a party man, totally devoted to Ceauşescu and without previous experience in the internal affairs ${ }^{57}$. Ion Stănescu never returned to the MAI again but he was not marginalized either. Until the fall of the regime in 1989 , he continued to occupy various governmental positions. ${ }^{58}$

There are several ironies of history to this story. In December 1989, when Romania was in turmoil as the sequence of events leading to his overthrow and execution began unfolding, Ceauşescu was again thundering against the internal affairs for not doing a good job in repressing what he called "acts of hooliganism". Alexandru Drăghici, although excluded and ostracized, lived a long life of retirement and did get to see Ceauşescu executed. He died in 1993.

\section{Conclusion}

Although built and supported on the repression carried on by the political police, the Communist regime in Romania had a complicated and fluctuating relation with the Securitate. The party-police relation which appeared to outside observers as a monolith was rarely so. During Stalin's time, GheorghiuDej himself felt threatened by an internal affairs apparatus that was controlled by a close associate of Ana Pauker whom he perceived as competitor. After his accession to power in 1965, Nicolae Ceauşescu too felt that MAI escaped his control and that his power could not be consolidated unless he subordinated the internal affairs and Securitate.

\footnotetext{
${ }^{56}$ ibid.

${ }^{57}$ Membrii CC al PCR..., 103.

58 ibid.
} 
Alexandru Drăghici was appointed head of internal affairs by GheorghiuDej whom he served faithfully. Due to his loyalty to the deceased leader and his control over the Securitate, Alexandru Drăghici was perceived by Ceauşescu as an adversary, perception encouraged by his personal rivalry with Drăghici. In order to secure his power, Ceauşescu committed himself to subordinating the Securitate and limiting Drăghici's influence. Various strategies were combined to that effect. The basic principle laid down by Ceauşescu to justify his assault on internal affairs was consolidation of the party and of the party's control over all fields of activity.

Such an approach proved successful in many ways. It prevented any opposition to changes because party men could only agree to consolidating party control. From another point of view, speaking about the party, in a general manner, confirmed the expectations for a collective leadership after the long rule of "patriarch" Gheorghiu-Dej. Similar expectations existed in the USSR after Stalin's death. Unity around the party also served to subdue society since the party was perceived as defender of Romanian national independence in front of Soviet hegemony, due to Gheorghiu-Dej's program of national Communism. In other words, Ceauşescu used the party as a disguise for pursuing full control over the political police.

Under this banner, Ceauşescu proceeded to an institutional reorganization aimed, on one hand, at limiting the influence and power base of Alexandru Drăghici and, on the other hand, to prepare the way for Ceauşescu's imposition of his own influence. This was the preparatory step before his major coup, the rehabilitation of former activist Lucrețiu Pătrășcanu, a rehabilitation which revealed his predecessor as a bloody murdered, along with his master tool, former minister of internal affairs Drăghici. In all his measures, both before and after Pătrășcanu's rehabilitation, Ceauşescu proved special caution and prudence for the Securitate apparatus. This demonstrated that his purpose was not justice or vengeance, but only control.

In the end, Ceauşescu's struggle for power goes to prove once again that Communist regimes were closely dependent on the political police apparatus but, more important, that this dependence did not always involve full party control over it, but rather a long and continuous fight the party had to carry in order to insure this control. At times, control over the political police was - as Khrushchev himself demonstrated much earlier - vital in processes of power succession under Communist regimes. 